\title{
In memoriam - wspomnienia pracowników Zakładu Pedagogiki Specjalnej o Profesorze Władysławie Dykciku
}

Przygotowując się do napisania artykułu wspomnieniowego o Profesorze Władysławie Dykciku, mieliśmy - byli i obecni pracownicy Zakładu Pedagogiki Specjalnej oraz byłe doktorantki - na uwadze konstatację Myśliwskiego, iż prawda o życiu każdego człowieka jest bardzo trudna nie tylko do uchwycenia, ale i do odtworzenia ${ }^{1}$. Dlatego przez cały czas przygotowań naszych wspomnień o Profesorze towarzyszyło nam pytanie o to, w jaki sposób najpełniej i najwierniej, jak tylko jest to możliwe, namalować słowem portret Profesora Dykcika. W związku z tym, że każda $\mathrm{z}$ nas $\mathrm{z}$ Profesorem zetknęła się $\mathrm{w}$ innym czasie i $\mathrm{w}$ innych okolicznościach, postanowiłyśmy stworzyć Jego „wielonarracyjny portret”, w tworzeniu którego każda z nas, Jego współpracowniczek, miała swój udział. Portret ten będzie przedstawiany w sześciu odsłonach, które być może Profesor Dykcik w swojej atencji do lapidarnych określeń nazwałby $6 \times$ O. Oto one.

Odsłona pierwsza: Adept pedagogiki specjalnej

W latach 60. ubiegłego stulecia sytuacja rodzin z dziećmi z głębszą niepełnosprawnością intelektualną $\mathrm{w}$ Polsce była bardzo trud-

1 W. Myśliwski, Gra z czasem, „Tygodnik Powszechny” 2013, 41(3353), s. 33. 
na. Życie takich rodzin było przepełnione poczuciem wstydu, upokorzenia, smutku i beznadziejności. Odrzucenie społeczne, z jakim się spotykały, było powszechne. W takiej rzeczywistości aktywny kontakt wtedy młodego studenta pedagogiki Włodka Dykcika z Kołem Pomocy Dzieciom Specjalnej Troski w Poznaniu był nieoceniony. Podczas spotkań z rodzicami okazywał im wiele ciepła, optymizmu i nadziei na lepszą przyszłość ich dzieci. Przez kilka lat organizował i prowadził kolonie letnie, turnusy wypoczynkowe dla dzieci, młodzieży i dorosłych z głębszą niepełnosprawnością intelektualną, na których dominowała u uczestników radość osiągnięć, wiara w swoje możliwości. Włodek potrafił rozśpiewać, rozbawić tych, którzy na co dzień najczęściej żyli w samotności, poczuciu porażek i smutku. Pięknie grał na akordeonie, muzyką porywał do tańca i śpiewu wszystkich - nawet najbierniejszych. Profesor Dykcik, najpierw jako student potem już jako pracownik naukowy, był wysoko ceniony przez rodziców, zwłaszcza matki, za rozmowy dające im tak potrzebną nadzieję na usprawnienie swoich dzieci. Nie koncentrował się na ich ograniczeniach rozwojowych, ale wręcz przeciwnie - na ich możliwościach i potrzebach. Wpajał rodzicom podstawowe zasady aktywizowania i wychowania dzieci, robił to zawsze w atmosferze zrozumienia i szacunku. Osoby z głębszą niepełnosprawnością intelektualną darzyły "Pana Włodka”, bo tak właśnie Go nazywały, niezwykłą sympatią. Zawsze gdy wśród nich się pojawił, witały Go z ogromną radością i prosiły, by pozostał z nimi jak najdłużej.

\section{Odsłona druga: Nauczyciel akademicki}

W pamięci studentów pozostawało zawsze pierwsze spotkanie z Profesorem (warto zauważyć, że wszystkie z obecnych pracowniczek Zakładu Pedagogiki Specjalnej to Jego byłe studentki). Profesor zwykł, podczas wykładu początkującego cykl zajęć, poznawać swoich studentów, pytając ich nie tylko o nazwiska i imiona, ale przede wszystkim o lokalne ojczyzny. Ta swoista mnemotechnika Profesora - przypisanie do miejscowości konkretnych osób - zaskakiwała 
skutecznością. Profesor pamiętał studentów, nawet tych, a może przede wszystkich tych, którzy pochodzili z małych miejscowości. Miał zwyczaj na egzaminie wymieniać studentów według ich miejsca zamieszkania, co budziło podziw wśród rzeszy studenckiej.

Innym zwyczajem Profesora Władysława Dykcika było zapraszanie na wykłady osobistości świata nauki oraz praktyków - pedagogów specjalnych innowatorów. Profesor dbał, by po wykładzie zaproszonych gości zawsze miała miejsce dyskusja prowokująca studentów do przemyśleń. Kiedy Profesor spotykał się na zajęciach ze studentami szczególnie zaangażowanymi, organizował dla nich hospitacje w szkołach i placówkach dla osób z niepełnosprawnością intelektualną. Studenci zwykle byli zaskoczeni faktem, jak wielu wychowanków placówek Profesor znał osobiście z turnusów rehabilitacyjnych, podczas których był opiekunem i wychowawcą.

\section{Odsłona trzecia: Pracownik naukowy}

Praca naukowa była dla Profesora zawsze najważniejsza. Przypominał nam, że trzeba jej poświęcić czas każdego dnia, nawet jeżeli przyjdzie człowiekowi siedzieć nad pustą kartką. Zawsze gdy gdziekolwiek wyjeżdżał, zabierał z sobą mnóstwo książek, by móc na miejscu pracować naukowo.

Liczne publikacje naukowe Profesora traktowały głównie o godności osoby z niepełnosprawnością, rodzicielstwie, odpowiedzialności. Wiele miejsca poświęcił zagrożeniom, uwarunkowaniom oraz uregulowaniom sytuacji psychospołecznej osób z niepełnosprawnością.

Osobnym wątkiem zainteresowań naukowych Profesora była teoria pedagogiki specjalnej. Rozwijał ją w myśl tradycji aksjologicznej zapoczątkowanej przez Marię Grzegorzewską, podkreślając jednocześnie dokonujące się zmiany paradygmatu oraz nowatorstwo rozwiązań w opiece, rehabilitacji i edukacji. Podręcznik Pedagogika specjalna - lektura obowiązkowa kolejnych roczników studentów pedagogiki i pedagogiki specjalnej² - doczekał się wielu wznowień.

${ }^{2}$ W. Dykcik (red.), Pedagogika specjalna, Wyd. Nauk. UAM, Poznań 2009. 
Jeszcze kiedy Profesor był z nami, podjął decyzję o kolejnym wydaniu - zrewidowanym i uwzględniającym współczesne przemiany $\mathrm{w}$ pedagogice specjalnej.

Wielokroć powtarzane na wykładach, spisane w książkach refleksje Profesora na temat jakości życia, samorealizacji, odpowiedzialności za los człowieka zagrożonego marginalizacją, konieczności wielostronnego spojrzenia na jakość instytucjonalnego wsparcia, uczestnictwa w kulturze, życiu społecznym stały się punktem odniesienia dla wielu pedagogów specjalnych.

Profesor dużą wagę przywiązywał również do udziału w konferencjach, podczas których skupiał się na bieżących problemach teorii i praktyki polskiej pedagogiki specjalnej, między innymi na problemie związanym z kwalifikacjami pedagogów specjalnych. Na konferencjach był nie tylko prelegentem, ale także duszą towarzystwa podczas części nieoficjalnych. Dzięki temu „konferencyjna monotonia bankietowa" zmieniała się we wspólną zabawę. Na przykład podczas konferencji w Krakowie ze strony Profesora padł pomysł, by jej uczestnicy reprezentujący poszczególne ośrodki akademickie Polski coś zaśpiewali bądź powiedzieli dowcipnego.

Pasja podróżowania i wpleciona $\mathrm{w}$ nią ciągła chęć poznawania tego, co nowe i jeszcze nieznane, znalazły swoje odzwierciedlenie w wadze, jaką Profesor nadawał współpracy z zagranicznymi ośrodkami naukowymi w Europie, zarówno zachodniej (uniwersytety w Kiel, Magdeburgu, Monachium), jak i wschodniej (uniwersytety w Brnie, Mińsku, Moskwie, Pradze, Wilnie). I podobnie jak Jego podróże nie ograniczały się tylko do Europy, tak i Jego kontakty naukowe poza nią wykraczały - Profesor współpracował również z ośrodkami naukowymi w USA i Kanadzie. Należy podkreślić, że wielką troską i zainteresowaniem otaczał zagranicznych studentów studiujących poznańską pedagogikę specjalną. Zawsze mogli oni liczyć na Jego wsparcie i pomoc bez względu na kraj i kontynent ich pochodzenia. Często gościł nie tylko ich samych, ale również ich rodziny $\mathrm{u}$ siebie $\mathrm{w}$ domu, serwując nierzadko tradycyjne dania kuchni polskiej przez siebie przygotowane. 
Odsłona czwarta: Kierownik Zakładu Pedagogiki Specjalnej

- niestandardowy Szef

W roku 1992 Profesor Dykcik został kierownikiem Zakładu Pedagogiki Specjalnej, wyłonionego z Zakładu Psychopatologii Dziecka i Pedagogiki Specjalnej. Został naszym Szefem, bo tak się do niego zwracałyśmy. By zintegrować zespół, Profesor wpadł na pomysł "święta zakładu”, to znaczy wspólnego wyjazdu raz do roku do różnych placówek, szkół przeznaczonych nie tylko dla osób z niepełnosprawnością intelektualną. Nierzadko "święto zakładu” było łączone ze wspólnym wyjazdem na konferencję. Dzięki temu poznałyśmy wiele szkół, domów pomocy społecznej oraz warsztatów terapii zajęciowej z różnych regionów Polski. Podróżowaliśmy autem Profesora, a On umilał jazdę opowieściami oraz dowcipami. Dbał, byśmy podczas podróży nie były głodne, co skutkowało czasami "spożywaniem posiłku” na polecenie służbowe. Często po drodze odwiedzaliśmy Jego ukochane Borzęciczki, o których wiele nam opowiadał.

Gdy liczba pracowników zakładu wzrosła i wspólne podróżowanie okazało się zbyt trudne ze względów organizacyjnych, Profesor wprowadził zwyczaj "stacjonarnego święta zakładu”, które odbywało się na Jego działce w Wagowie lub na tarasie domu na os. Marysieńki w Poznaniu. Było wspólne biesiadowanie, zabawa i długie dyskusje dotyczące nie tylko pedagogiki specjalnej.

Warto wspomnieć, że ze swoich licznych podróży Profesor przywoził nam drobne upominki. Często do nas dzwonił, niekoniecznie z powodów służbowych. Zawsze byłyśmy pod wrażeniem radości i afirmacji życia, która biła od Profesora, Jego dowcipu i optymizmu.

\section{Odsłona piąta: Kolekcjoner}

Wielką estymą darzył Profesor Dykcik książki. Miał ich pełne półki. Zawsze wrażenie na nas robiła, jak mówiłyśmy między sobą, „biblioteka Profesora”. Znalazły się w niej niemal wszystkie wydawane $\mathrm{w}$ Polsce publikacje traktujące o pedagogice specjalnej, mię- 
dzy innymi książki Marii Grzegorzewskiej, Janiny Doroszewskiej czy Aleksandra Hulka. Jeśli ktoś z nas zajmował się określonym problemem, Profesor pamiętał o nim. Przynosił książki ze swojej biblioteki, również te niedawno wydane, nieobecne jeszcze w księgarniach.

W domu Profesora oprócz księgozbioru można było podziwiać ponad dwutysięczną kolekcję sów. Każda była inna i z każdą wiązała się inna historia, którą Szef doskonale pamiętał i chętnie opowiadał. Podczas tych opowieści podziwiałyśmy Jego pamięć i sposób narracji. Swojemu sowiemu towarzystwu poświęcił książkę, w której została opisana część jego kolekcji³.

\section{Odsłona szósta: Nieobecność}

Trudno nieobecność osoby i pustkę po niej wyrazić słowami. Doświadcza się jej bowiem indywidualnie w intymnym zaciszu samego siebie, swoich myśli. Dlatego każdej z nas, współpracowniczek Profesora, przyjdzie na swój sposób zmierzyć się z Jego nieobecnością i dotykać pustki po Nim. Dobrze, że zostały nam wspomnienia i książki Profesora.

Krystyna Błachnio Marzena Buchnat Anna Drozdowicz Monika Karwacka

Danuta Kopeć

Sandra Krajczy Jolanta Lauch-Żuk Katarzyna Pawelczak Beata Tylewska-Nowak Aleksandra Załustowicz

${ }^{3}$ W. Dykcik, Sowy. Kolekcja z podróży po Polsce i świecie, Wyd. PTP, Poznań 2009. 